\title{
The Role of Oxidative Stress and Hormones in Controlling Obesity
}

\begin{abstract}
Marina Di Domenico ${ }^{1,2}$, Federica Pinto ${ }^{1}$, Lucio Quagliuolo ${ }^{1}$, Maria Contaldo ${ }^{3}$, Giuliana Settembre ${ }^{1}$, Antonio Romano ${ }^{3}$, Mario Coppola ${ }^{1}$, Kenan Ferati ${ }^{4}$, Arbëresha Bexheti-Ferati ${ }^{4}$, Antonella Sciarra ${ }^{5}$, Giovanni Francesco Nicoletti ${ }^{6}$, Giuseppe Andrea Ferraro ${ }^{6 *}$ and Mariarosaria Boccellino ${ }^{1}$
\end{abstract}

\begin{abstract}
${ }^{1}$ Department of Precision Medicine, University of Campania Luigi Vanvitelli, Naples, Italy, ${ }^{2}$ Department of Biology, College of Science and Technology, Temple University, Philadelphia, PA, United States, ${ }^{3}$ Multidisciplinary Department of Medical-Surgical and Dental Specialties, University of Campania Luigi Vanvitelli, Naples, Italy, ${ }^{4}$ Faculty of Medicine, University of Tetovo, Tetovo, Macedonia, ${ }^{5}$ Department of Translational Medicad Sciences, University of Campania Luigi Vanvitelli, Naples, Italy, ${ }^{6}$ Plastic Surgery Unit, Multidisciplinary Department of Medical-Surgical and Dental Specialties, University of Campania Luigi Vanvitelli, Naples, Italy
\end{abstract}

OPEN ACCESS

Edited by:

Rajiv Saini,

University of Medicine, Albania

Reviewed by:

Francesco Oriente

University of Naples Federico II, Italy

Simona Nanni,

Università Cattolica del Sacro

Cuore, Italy

*Correspondence:

Giuseppe Andrea Ferraro

giuseppe.ferraro@unicampania.it

Specialty section: This article was submitted to

Translational Endocrinology, a section of the journal

Frontiers in Endocrinology

Received: 15 April 2019

Accepted: 19 July 2019

Published: 13 August 2019

Citation:

Di Domenico M, Pinto F, Quagliuolo L, Contaldo M, Settembre G, Romano A, Coppola M, Ferati K, Bexheti-Ferati $A$ Sciarra A, Nicoletti GF, Ferraro GA and Boccellino M (2019) The Role of

Oxidative Stress and Hormones in Controlling Obesity.

Front. Endocrinol. 10:540. doi: 10.3389/fendo.2019.00540
The accumulation of adipose tissue in the body occurs because the energy introduced with food and drink exceeds that expense, but to understand why this imbalance is established and why it is maintained over time, it is important to consider the main causes and risk factors of excess weight. In this review, we will refer to the main factors linked to obesity, starting from oxidative stress to hormonal factors including the role of obesity in breast cancer. Among the many hypotheses formulated on the etiopathology of obesity, a key role can be attributed to the relationship between stress oxidative and intestinal microbiota. Multiple evidences tend to show that genetic, epigenetic, and lifestyle factors contribute to determine in the obese an imbalance of the redox balance correlated with the alteration of the intestinal microbial flora. Obesity acts negatively on the wound healing, in fact several studies indicate morbid obesity significantly increased the risk of a post-operative wound complication and infection. Currently, in the treatment of obesity, medical interventions are aimed not only at modifying caloric intake, but also to modulate and improve the composition of diet with the aim of rebalancing the microbiota-redox state axis.

Keywords: obesity, oxidative stress, thyroid, gut hormones, microbiota, wound healing

\section{INTRODUCTION}

\section{Obesity}

In the last few years the changes in diet and lifestyle resulted in an prevalence of overweight and obesity. Obesity rates have increase in the last several decades; more than $30 \%$ of the US population is now classified as obese $(1,2)$. The prevalence of these individuals varies from country to country but in developed countries, most of the population are affected. Just think that in America about a third of population are obese with a body mass index $>30 \mathrm{~kg} / \mathrm{m}^{2}$ (3). The variation from country to country implies that environmental factors are the major determinant of disease prevalence. Obesity is thought to be the second most preventable cause of death after smoking; moreover Roland Sturm in his study suggests that the health care costs of obesity exceed those of smoking (4). In particular, he compared the effects of obesity, overweight, smoking, and problem drinking on health care. Obesity is associated with a $36 \%$ increase in inpatient and outpatient spending and 
a $77 \%$ increase in medications, compared with a $21 \%$ increase in inpatient and outpatient spending and a $28 \%$ increase in medications for smokers and smaller effects for problem drinkers. Obesity is also increasing in children. The consumption of sweetened beverages is associated with childhood obesity but also because they spend a considerable part of their lives watching television $(5,6)$.

Obesity is a complex disease associated with disturbances in lipid and glucose metabolism, chronic inflammation, oxidative stress, and an increased risk of several diseases, most notably cardiovascular diseases, diabetes, and cancers $(7,8)$. In obesity, the skin is one of the main organs to be affected through a complex interaction of hormones, adipocytokines, and mechanical factors. The most common skin diseases associated with obesity are keratosis pilaris, cellulite, candidiasis/dermatophytosis, psoriasis, and Lichen planus $(9,10)$. Obesity is an important risk factor for several malignancies. In fact, higher body mass index (BMI) increases the incidence of many types of cancer. The role of obesity in head and neck squamous cell carcinoma (HNSCC) is not welldefined. However, obesity may be applied to predict prognosis of oral squamous cell carcinoma (OSCC) patients $(11,12)$. The expression of adhesion molecules such as cadherins during the epithelial mesenchimal transition (EMT) can improve OSCC prognosis and therapy $(13,14)$.

Adipose tissue is no longer viewed as a passive source of free fatty acids (FFA) but as an active endocrine and paracrine organ secreting an ever-increasing number of mediators named adipokines. These secreted proteins include tumor necrosis factor (TNF)- $\alpha$, resistin, IL-6, acylation-stimulating protein (ASP), angiotensinogen (AGT), plasminogen activator inhibitor1 (PAI-1), leptin, and adiponectin. They participate in diverse metabolic processes including food intake, fat metabolism, feeding behavior, haemostasis, vascular tone, energy balance, and insulin sensitivity regulation of energy balance (15-18). Leptin and adiponectin exert a beneficial effect on energy balance, insulin action, and vasculature while excessive production of fatty acids (FA) and TNF- $\alpha$, IL- 6 , and resistin is deleterious because they might deteriorate insulin action. Angiotensinogen and PAI- 1 are likely to participate in the vascular complications linked to obesity (19). In obese individuals, excessive production of ASP, TNF- $\alpha$, IL-6, or resistin deteriorates insulin action in muscles and/or in liver, while increased angiotensinogen and PAI-1 secretion favors hypertension and impaired fibrinolysis $(20-22)$. Leptin is a $16-\mathrm{kDa}$ protein synthesized mainly in adipose tissue in fact adipocytes are the most important source of leptin (23). The primary role of leptin is the control of appetite, mutations in the leptin gene, or leptin receptor gene develop obesity $(19,24)$. Several studies indicate a direct role of leptin in lipid metabolism mediated both through central and peripheral actions of it (Figure 1). In rodent models, central administration of leptin increased resting metabolic rates, resulting in reduced triglycerides content in both adipose and non-adipose tissues, as well as reduced plasma free FA and triglycerides levels. Leptin may also have autocrine or paracrine effects on adipocyte fat metabolism. The incubation of mouse adipocytes with leptin stimulates lipolysis of intracellular triglycerides (TG), and this effect was not seen in in diabetes mice lacking leptin receptors $(25,26)$.

\section{THE ROLE OF OXIDATIVE STRESS}

Experimental evidences suggest that the sources of oxidative stress in obesity are different as hyperglycemia, hyperleptinemia, inadequate antioxidant defenses, increased muscle lipid levels, increased muscle activity, increased free radical formation rates, alteration of mitochondrial function, endothelial dysfunction, and chronic inflammation $(27,28)$. Many studies have suggested that natural compounds as phytochemicals in fruits and vegetables can be important modulators in terms of the risks associated with obesity. In particular, Martineau and Sakaida have demonstrated the anti-diabetic and anti-hypertensive properties of the blueberry in vitro $(29,30)$. In addition, in obese Otsuka Long-Evans Tokushima Fatty (OLETF) rat, a rat model that develops a syndrome with multiple metabolic and hormonal disorders that shares many features with human obesity, it has been shown that the blueberry leaves extracts, especially flavonol glycoside and proanthocyanidin, had a hypolipidemic effect on OLETF rats, and suggest that an infusion of blueberry leaves extracts could be useful as a dietary hypolipidemic component (31).

Oxidative stress and inflammation, which occur in obesity, can induce DNA damage and inhibit DNA repair mechanisms that lead to an increase in mutation frequency and can alter gene expression. DNA damage associated with obesity can promote cancer growth by favoring cancer cell proliferation and migration, and resistance to apoptosis (32-37).

In obesity, during the hyperglycaemia, the intracellular glucose overload increases the glycolysis and the Krebs cycle, generating an increase of $\mathrm{NADH}$ and $\mathrm{FADH}_{2}$ that lead to the end of the oxidative phosphorylation to the superoxide production. In fact, augmented respiration may not be bioenergetically efficient due to leaking mitochondria and thereby promote excessive hepatic oxidative stress, challenging hepatocellular anti-oxidant defense mechanisms (38-40). In non-alcoholic fatty liver (NAFL) augmented hepatic oxidative stress $\left(\mathrm{H}_{2} \mathrm{O}_{2}\right.$ and lipid peroxides) and oxidative DNA damage (8-OH-deoxyguanosine) was balanced by reduced antioxidant defense capacity and increased inflammatory response. If the antioxidant defense mechanism fails to counteract oxidative stress, mitochondrial functionality decreases developing hepatic insulin resistance, systemic inflammation, and NAFLD progression to steatohepatitis (NASH). This suggests an adaptation of hepatic mitochondria in obese humans without NASH (41). The increase in plasma FFA promotes the generation of $\mathrm{O}^{2-}$ in the mitochondrial electron transport chain by inhibiting the translocation of adenine nucleotides. Conjugated fatty acids are susceptible to oxidation, stimulate the formation of radicals, and enhance the accumulation of oxidative byproducts (42). Various studies have suggested an association between levels of different markers of systemic oxidative stress and the accumulation of fat (43). There is an important role for 


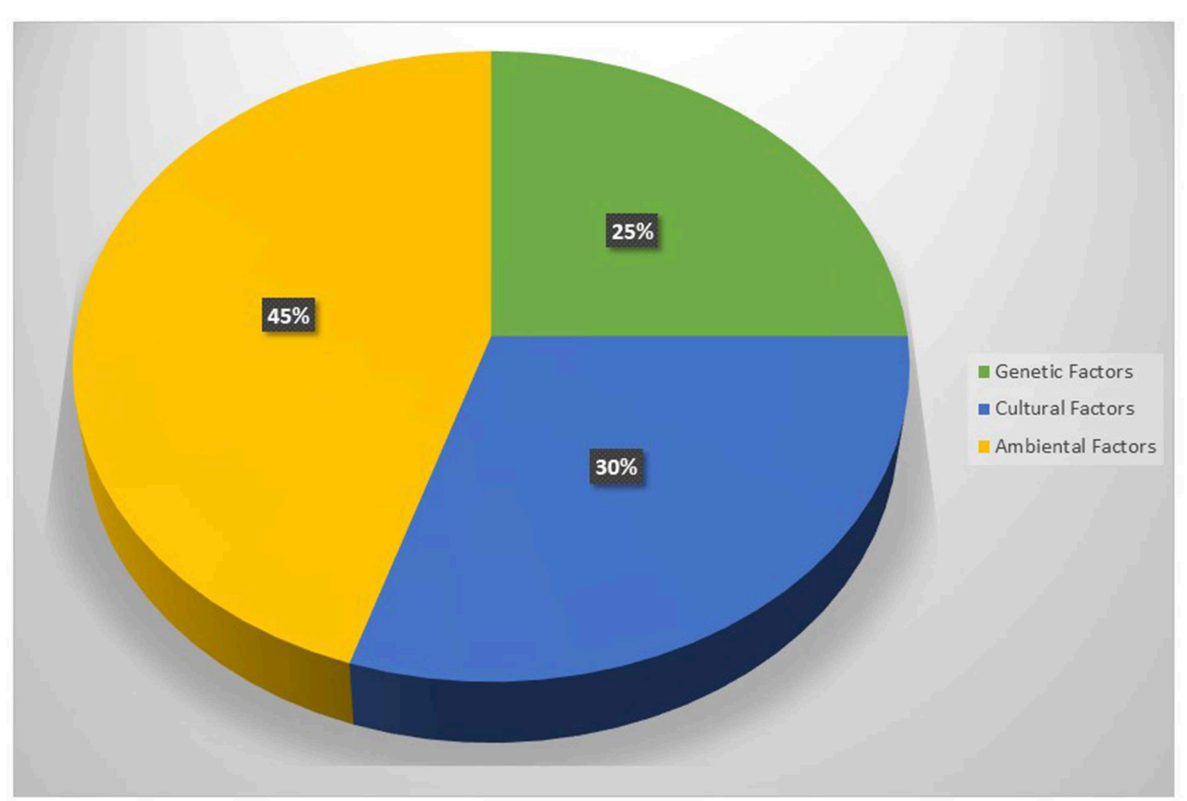

FIGURE 1 | The main causes of obesity.

adipose tissue in the production of ROS. The increase in ROS in adipose tissue has been associated with increased expression of NADPH oxidase and reduced expression of anti-oxidant enzymes such as SOD and catalase (44). The removal of free radicals occur through enzymic and non-enzymic antioxidants but an increase in weight can reduce the antioxidant capacity of plasma (45). The weight loss and BMI reduction might induce an increase of antioxidant enzymes activities in the obese individuals. Moreover, the activity of these enzymes is influenced by the daily intake of antioxidant vitamins $(46,47)$. In the obese individuals, inadequate concentrations of vitamins and minerals cause the observed impaired antioxidant defense $(48,49)$. In fact an increase in BMI has been found to be related to low levels of carotenoids, vitamin $\mathrm{C}$, and vitamin E. Adequate intracellular antioxidant defenses are necessary to maintain the antioxidant-pro-oxidant balance in tissues. Oxidative stress also plays an important role not only in biochemistry and cell biology but also in the nutritional sciences, environmental medicine, and molecular knowledge-based redox medicine. Therefore, research on this topic is relevant for maintaining health condition, for using drugs and for a better understanding of various diseases. Oxidative stress is closely associated with pathological mechanisms and symptoms of urinary bladder dysfunction. In particular, partial bladder outlet obstruction (PBOO) causes pathological changes in bladder tissues through induction of oxidative stress $(50,51)$. Low levels of ROS are considered essential for neuronal development and function, while excessive are hazardous. Indeed, the brain, with its high energy demand, and weak antioxidant capacity becomes an easy target of excessive oxidative stress. Thus, ROS accumulation is a cellular threat that, if it bypasses counteracting mechanisms, can cause significant neuronal damage (52). The rapid development and use of nanotechnology products has led to their ever wider use in the biomedical field. Nanoparticles are fundamental tools for medicine and biology, as they can be used for biomedical applications from diagnosis to therapy. There are many experimental researches for the production and characterization of biocompatible nanoparticles that can become efficient carriers to be used in drug delivery in different types of diseases. Biological systems and nanoparticles can be used to study cell toxicity, apoptosis in human mucosa, in particular nanoparticle biomolecular corona can be correlated to physiological and pathological conditions (53-55). Deficiencies in vitamins and minerals can also contribute to the development of an impaired antioxidant defense in the pathogenesis of obesity $(56,57)$. Kimmons et al. have examined the association between BMI and micronutrient levels. In particular, they have measured nutritional biomarker levels in the serum such as alpha-carotene, beta-carotene, lycopene, vitamin E, vitamin $\mathrm{C}$, vitamin $\mathrm{A}$, vitamin $\mathrm{D}$, folate, and vitamin B12. Overweight and obese adults had higher odds of low levels for a number of nutrients than normal-weight adults. Odds of being low in multiple micronutrients was most common among overweight and obese premenopausal women (58). The chronic low-grade state of inflammation in obesity is another important source of oxidative stress. TNF- $\alpha$, IL- 6 , IL- 8 , and IL-1 are the most well-known mediators of the early inflammatory response that are over-expressed in obesity and increase the activities of Nicotinamide Adenine Dinucleotide Phosphate (NADPH) oxidases (NOXs) and the production of superoxide anion (59-61). Adipocytes are the most important source of leptin and plasma leptin concentrations are associated with the amount of adipose tissue. Leptin influences appetite, in fact its mutation or mutation in its receptor leads to obese subjects $(20,24)$. 
Leptin plays an important role in obesity-induced oxidative stress. It activates NOX and induces the production of reactive intermediates such as $\mathrm{H}_{2} \mathrm{O}_{2}$ and hydroxyl radical (Figure 2). In a rodent model, leptin injection caused higher levels of plasma and urinary lipid hydroperoxide, malondialdehyde (MDA), isoprostane, and protein carbonyl content. In addition, leptin also stimulates the production of proinflammatory cytokines and reduces the activity of the cellular antioxidant paranoxase-1 (PON-1) $(62,63)$. The activation of metabolic pathways generate increased of free radicals and electron transport chain activity. This leads to exacerbate the cellular respiration rate and oxygen uptake in muscle tissue during physical activities. Obese individuals are also mechanically less efficient during exercise and this insufficiency contributes to the increased energy expenditure for a given exercise load. An increase in mitochondrial respiration for energy production imply higher levels of lipid hydroperoxide in obese people $(64,65)$. Obesity is associated with higher concentrations of angiotensin II that promote oxidative stress in vasculature through several mechanisms including activation of NOX, formation of $\mathrm{O}_{2}^{-}$, and production of $\mathrm{H}_{2} \mathrm{O}_{2}$ (66). Excessive energy substrate causes mitochondrial dysfunction, which has been linked to the dysregulated secretion of adipokines, defects in fatty acid oxidation, increased production of ROS, and alteration of glucose homeostasis (67). Moreover, during the adipocyte differentiation process, the mitochondrial biogenesis and activity increase rapidly. These organelles play a central role in ATP production, energy expenditure, and disposal of ROS. When there is an excess of electrons as in obesity, a reduction of oxygen occurs resulting in the formation of potentially toxic-free radicals $(68,69)$. Diet is another possible contributing factor in the generation of ROS during obesity. In fact, consumption of a high-fat diet may alter oxygen metabolism. Moreover, obese individuals possess a lower dietary intake of protective phytochemicals rich in antioxidants such as $\beta$-carotene, vitamin $\mathrm{E}$, and $\mathrm{C}$, zinc, selenium, whereby it generate an inadequate antioxidant defense (70).

\section{THYROID HORMONES}

Thyroid dysfunction is highly widespread in the population. National data suggest that hypothyroidism is present in $4.6 \%$ of the US, and hyperthyroidism in $1.3 \%$. Thyroid dysfunction is very prevalent in obese subjects, in fact it was observed that among about 800 obese patients seen for bariatric surgery evaluation about $20 \%$ of this had elevated serum TSH (71). Recent clinical studies show the correlation between thyroid treatments and weight change (Figure 3). Patients with hypothyroidism have a persistent weight while following a diet, whereas patients with hyperthyroidism frequently present a weight loss. It was observed that weight decreases after treatment for hypothyroidism. Different studies describe weight change after the start of treatment for thyroid dysfunction, in particular, it was observed that more than $50 \%$ of patients with hypothyroidism lost weight after the start of levothyroxine therapy (L-T4) and 2 years following initiation of treatment, they had regained their baseline weight. Another study looked at the effects of liothyronine (L-T3) compared to treatment with L-T4. Treatment with L-T3 (19 weeks) resulted in significant weight loss (1.8 kg on average) and a significant decrease in fat mass (72). The close relationship between body weight and hormonal function is also demonstrated in a retrospective study, in which 120 patients that have achieved euthyroidism with thyroid hormone therapy 1 year following total thyroidectomy was compared with treated hypothyroid individuals who did not underwent thyroidectomy. After a year, the thyroidectomised patients had experienced significantly more weight gain (3.1 vs. $2.2 \mathrm{~kg}, p=0.004)$ than individuals who did not undergo thyroidectomy (73-75). The state of the thyroid can affect the distribution and quantity of the adipose tissue. In several studies it has been observed that the amount of subcutaneous fat and subcutaneous adipose tissue is inversely proportional with free thyroxine (FT4) levels whilst the increase in TSH is correlated with the thickness of subcutaneous fat (76). Indeed it was demonstrated a positive correlation between triiodothyronine (T3) and body weight. The relationship between the state of the thyroid and obesity is bidirectional: not only does thyroid function affect the state of obesity but obesity also affects thyroid function. The reason for the elevations in both TSH and T3 is attributable to leptin $(77,78)$. During caloric restriction there is a reduction in the concentration of leptin, thyroid hormones (T3) and catecholamine. This allows a metabolic adaptation that persists, hinders further weight loss, and predisposes some subjects to regain weight. In particular, it has been shown that in response to caloric restriction the leptin concentration decreases within $24 \mathrm{~h}$, regardless of circadian changes. The hypothalamus responds by decreasing the levels of thyroid hormones and sympathetic activation and skeletal muscle by increasing the efficiency of the mitochondria $(79,80)$. It can therefore be concluded that both serum TSH and T3 are dramatically increased in obese and it is caused, at least in part, by an impaired leptin production (81-83).

\section{GUT HORMONES}

The gastrointestinal tract, that is largest endocrine organ and its secretion of important gut hormones such as ghrelin, cholecystokinin (CCK), peptide YY (PYY), and glucagon like peptide-1 (GLP-1) plays a central role in metabolism and in maintaining of the baseline weight. This hormones regulate metabolism coordinating appetite, digestion, absorption, and nutrient disposal. The main role of intestinal hormones is to promote the absorption of nutrients but an imbalance of these hormones causes serious damage to health $(84,85)$. Gastrointestinal hormones play a central role in control of insulin secretion, for this reason they are essential for body weight and blood glucose control. In fact, bariatric surgery is currently the most successful treatment for the treatment of type 2 diabetes and obesity. This data suggests the close relationship between intestinal hormones and obesity (86). Gut hormones concentration varies between individuals and this depends on physiological and pathological conditions of individual. 
Metabolic changes, increased adiposity, altered diet are all factors that affect the production of these hormones with serious damage to health in obese subjects (Figure 4). The incretins are hormones produced by some cells in the intestine and released into the blood during a meal. The most important incretins are glucagonlike peptide 1 (GLP-1) and glucose-dependent insulinotropic polypeptide (GIP), both of which have the effect of glucosedependent promotion of insulin release by pancreatic beta cells. Furthermore, GLP-1, combined with the increase in insulin levels, reduces glucagon secretion by the alpha cells of the pancreas. Therefore, during a meal, the increase in incretin levels helps, in a glucose-dependent manner, to release a greater share of insulin and to produce less glucagon, obtaining a better control of glycemia, the so-called "incretinic effect." In healthy individuals "the incretinic effect" is interrupted after $2-5 \mathrm{~min}$ by an enzyme: DPP-IV or Di-Peptidyl-Peptidase IV $(87,88)$. A reduction in GLP1 secretion in the gastrointestinal tract was observed, in obese subjects with diabetes mellitus. The somministration of GLP-1 is efficacious in improving glycaemia in T2DM patients (87-89). A limit to the therapeutic use of GLP-1 is its short halflife, due to rapid degradation by dipeptidyl peptidase 4 (DPP4). To avoid this problem, DPP4-resistant GLP-1 analogs have been developed that possess enhanced half-lives, making treatment efficient. GLP-1 analogs are only licensed for T2DM, but some researchers have tested their use for the treatment of obesity without diabetes. It was showed that liraglutide (an analogous of GLP-1 in commerce), at doses of up to $3.0 \mathrm{mg}$ daily, was able to induce weight losses of up to $7.2 \mathrm{~kg}$ on average (87). In obese subjects also the concentration of the Peptide YY is altered. Peptide YY (PYY) is expressed by L-cells of the intestinal mucosa of the ileum and colon and belongs to the family of neuropeptide Y (NPY) along with pancreatic polypeptide (PP). It inhibits intestinal contractions, pancreatic and gastric secretions and reduces appetite (90). The level of PYY in the blood increases after a meal and remains high for a few hours suggesting its role as a satiety factor $(91,92)$. It arrives, through the bloodstream, to the arcuate nucleus of the hypothalamus where it acts on the orissigenic neurons by inhibiting the release of NPY and reducing hunger $(93,94)$. A study in volunteers suggests that PYY3-36 may increase insulin secretion in response to a meal, with an increase in glucose levels, suggesting that with PYY3-36 insulin sensitivity is reduced. PYY3-36 analogs are in experimentation for obesity and Diabetes mellitus type 2 treatments (95). In humans, fasting PYY and post-glucose GLP1 concentrations are inversely related to BMI, suggesting that low levels of PYY and GLP1 may pre-dispose to obesity (96).

\section{Microbiota}

The intestinal microbiota, the complex and dynamic population of micro-organisms that inhabits intestine, plays a key role in the absorption of nutrients, in the accumulation of energy and in the regulation of various metabolic pathways, able to influence body weight (97).

Saliva plays an important role in determining the composition and activity of the oral microbiota. The molecules coming from saliva form a conditioning film on oral surfaces, thus providing receptors for bacterial attack $(98,99)$.

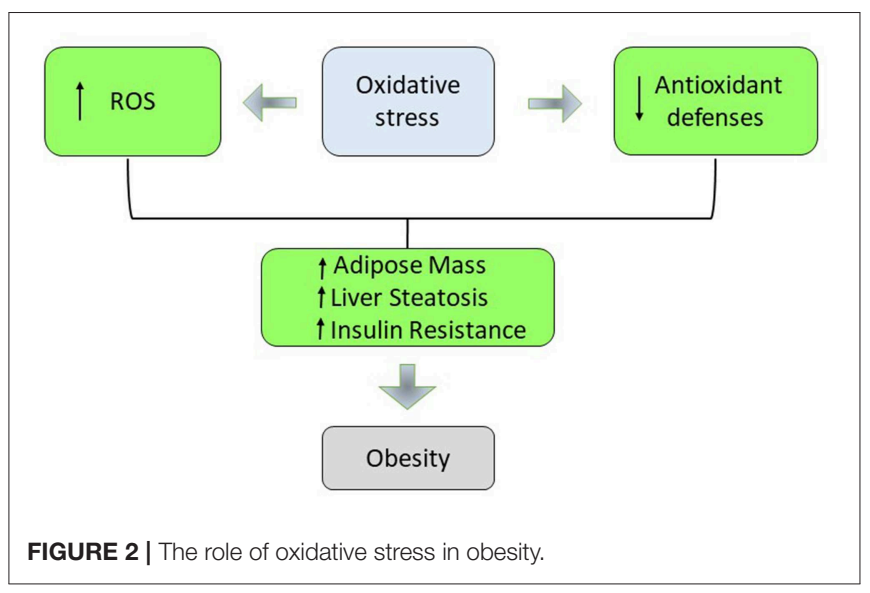

It has been observed that the microorganisms that colonize the gastrointestinal tract are not only almost inert hosts but are active protagonists of interactions between the gastrointestinal tract and the neuro-immuno-endocrine system $(100,101)$. The colonic microbiota produces several metabolites, many of these modulate the activity of the surrounding host enteroendocrine cells population. Human enteroendocrine cell responding to infection to chlamydia trachomatis are detected in gastrointestinal tract $(102,103)$. The microbiota derived luminal metabolome is the sum of many bacterial species and depends on the quantity and nature of the bacterial population, as well as the composition of the nutrients. The inter-relationship between IgAs and the microbiota is an open question. Even though recent publications have shown that IgAs can participate to microbiota diversification and that the microbiota can drive IgA production in a T-cell-independent manner, it is still unclear how the two are interacting and influencing each other (104). Microbioma metabolites modulate several of enteroendocrine cells population pathways, including expression profiles, hormone biosynthesis, and stimulus-secretion coupling pathways. In primary cultures it was shown that the expression of the PYY gene was induced by butyrate, a short chain fatty acid (SCFA) produced by bacterial fermentation of the fibers, via a pathway linked to the inhibition of histone deacetylase (HDAC). Thus, the consumption of fibers improve satiety in humans (105-108). Studies conducted on mouse models have shown that the microbiota of obese mice promotes the extraction of additional calories from the diet, favoring weight gain. Furthermore, by transplanting the intestinal microbiota of obese mice or skinny mice into lean, aseptic mice, mice that had received the microbiota from the obese were able to extract more calories from the foods showing a significantly greater accumulation of fat than the mice that received the microbiota from lean mice (109). The alteration in the intestinal microbial composition of humans is associated with obesity; in obese subjects the relationship between the two bacterial groups that dominate the human gut, Firmicutes, and Bacteroidetes, with a relative abundance of the first to the detriment of the latter, changes $(110,111)$. The differences in the extraction of calories from substances ingested with food can be largely dependent on the composition 


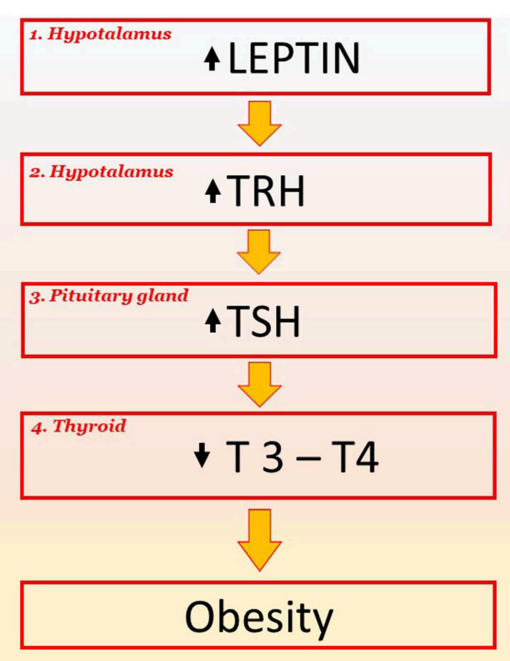

FIGURE 3 | The key role of TSH signaling and their downstream effectors in pathological phenomena and obesity. Leptin stimulates the production of TRH in the hypothalamus (point 1). An increase in TRH induces an increase in TSH in the pituitary gland (point 2); this increase results in a decrease in the hormones T3 and T4 in the thyroid (point 3). The reduced production of T3 and T4 reduces the basal metabolism by $40 \%$ and this favors obesity. TRH, Thyrotropin-releasing hormone; TSH, Thyroid-stimulating hormone; T4, thyroxine; T3, triiodothyronine.

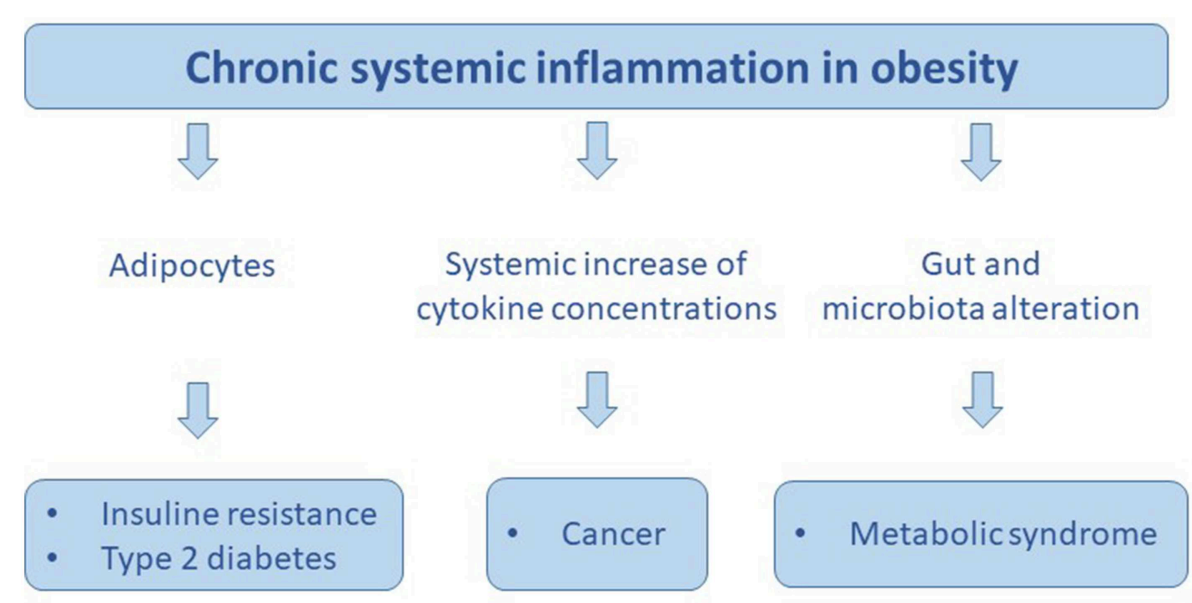

FIGURE 4 | The chronic sistemic inflammation in obesity promotes: insuline resistance, type 2 diabetes, cancer, and metabolic syndrome.

of the intestinal microbiota and, at the same time, weight loss is able to restore the normal intestinal microbial composition, confirming the link between microbiota and obesity $(112,113)$. Currently it is increasingly possible, to use the manipulation of the intestinal microbiota as a therapeutic strategy to regulate the energy balance in obese, diabetic or diagnosed with metabolic syndrome (114). In fact, several studies have shown the benefit of supplementation with probiotics in weight loss interventions; for example, low-calorie diets associated with the consumption of probiotics favor a more substantial weight loss and a reduction of the upper visceral fat, compared to diet alone. Furthermore, the use of probiotics allows faster weight loss in patients undergoing bariatric surgery (115). The usage of pre-biotics, such as fructan (prebiotics obtained from chicory root) or arabinoxylans (obtained from bran) also would reduce fat mass and inflammation, favoring the colonization of "good bacteria" inside the microbiota, thus strengthening the intestinal defenses (116).

\section{BREAST CANCER}

Breast cancer (BCa) is the most common cancer among women both in developed and in developing countries (117). In young women, namely 40 years old or younger, hormone responsive tumors are associated with epigenetic and hereditary factors $(118,119)$. Deregulation of epigenetic mechanisms may lead to human diseases including cancer and several dietary compounds such as catechins, curcumin, resveratrol 
exhibit potent anti-tumor activities through the reversion of epigenetic alterations (120-123). Activation-inactivation of hormone binding sites depends by the phosphorylation of a calmodulin stimulated tyrosine kinase (124-126). Breast cancer in young women are almost $7 \%$ of the diagnosed women in Western populations (127). Considering that most of them have tumors positive to estrogen receptors, it is important to underline that in premenopausal period the ovaries represent the source of estrogen, while in postmenopausal period the main source is the adipose tissue. Interplay steroids receptors and neoplastic progression in sarcoma and adenocarcinoma tumors is known in hormone responsive signaling (128, 129). The excessive storage of lipids that occurs in obesity leads to important changes in adipose tissue, as adipocyte cell death and the recruitment of macrophages, with a consequent chronic low-grade inflammation and the activation of NFkB, also in the breast fat; as well-known, it may have important effects for tumor, both in its development and in its progression. This process is associated with severe alterations in growth and proliferation signaling, e.g., mitogen-activated protein kinase (MAPK) signaling, nuclear factor $\kappa$ B (NFкB) signaling, by deregulation of signal transduction and proteinprotein interactions (PPI) (130-132). Adipose tissue plays a central role in the alteration of tumor microenvironment releasing FFA, inflammatory cytokines, and adipose stem cells that can contribute to both to the remodeling of tumor microenvironment. All molecules in concert cooperate to creating the premetastaticed niches. Citokines and growth factors released in the neoplastic site are a biomarker signature and play a central role in the formulation of early tumor diagnosis and therapy. A treatment approach for invasive breast carcinoma and other cancer could be based on electroporation (133137). As a matter of fact, obesity and metabolic syndrome are universally recognized as risk factors for a number of cancers, increasing in particular the risk of postmenopausal ER-positive BCa by over 50\% (138). The mechanism that can explain this connection is still not completely clear, though it seems that the increase of serum insulin and insulin growth factors, as well as the higher levels of estrogens and the already mentioned inflammatory factors, may be the most common factors, identified as cancer signature for the clinical outcome of neoplastic patients. Recently, microRNAs (miRNAs) have shown promise as new biomarkers for many cancers, including metastatic breast cancer (139-141). Insulin-like growth factor-1 receptor (IGF-IR) activation is associated with the invasion and metastases in $\mathrm{BCa}$ and it has a role with the estrogen receptor in promoting tumor growth $(142,143)$. Vascular endothelial growth factor (VEGF) in concert with steroid receptors can be used for differential diagnosis of benign and malignant origin $(144,145)$. Moreover, hypercholesterolemia, that often affects obese women, may itself represent an independent risk factor. In fact, the $\mathrm{BCa}$ incidence, as well as its recurrence, is lower for patients that assume statins to reduce cholesterol level (146). A recent study pointed out fatty acids, and in particular low basal docosahexaenoic acid (DHA) levels as an important factor in increasing BCa risk and even in affecting prognosis and response to treatments, though the studies about an anticancer effect of DHA are often controversial (147). Liquid biopsy is used in breast and other cancer diagnosis. Furthermore, circulating tumor cells (CTC) plasma count can be assessed to determine the stage and prognosis of epithelial cancers (148). Over-expression of matrix metalloproteinases (MMPs) and tissue inhibitor of metalloproteinase are associated with the relapse of neoplatic disease, metastasis, shorter overall survival in breast, and other tumors MMPs/TIMPs ratio could be useful in the follow-up of these patients (149). In general, about $35 \%$ of cancer cases is influenced by nutrition (150) and in particular, several studies showed that gaining weight during postmenopausal life increases the risk of developing breast cancer, while a weight loss is associated with a reduced risk. In fact, several studies show that the state of low-grade chronic inflammation due to obesity may be reversible through a controlled diet and exercise, though exercise alone cannot do it (131). A 12 months weight loss diet, associated with physical exercise in postmenopausal women resulted in the reduction of several biomarkers of inflammation, suggesting that this effect may be crucial to reduce the risk of $\mathrm{BCa}$ as well as of other cancers in obese postmenopausal women (151). A valid example comes from a review of 33 intervention studies in which $1 \mathrm{~kg}$ of weight loss corresponds to $0.13 \mathrm{mg} / \mathrm{l}$ reduction of Creactive protein (152). Diet and exercise are obviously modifiable factors, which may influence both the risk and recurrence of BCa. However, several studies such as Feigelson's have shown that the impact of weight loss on breast cancer risk has been difficult to quantify (153). The risk is strictly connected to serum sex hormones namely estrogens and androgens: it has been shown that the risk is up to two-fold in postmenopausal women with higher endogenous sex hormones levels. Weight loss induced by both diet and exercise has been demonstrated to have an important favorable effect on some of these hormones (154). Moreover, even during the follow up of BCa treatment, a diet rich in fruits and vegetables and poor in fat intake may reduce the risk of relapse after 5 years (155). Since 1999 , Saxe et al. (156) analyzed the behavior of 149 women after $\mathrm{BCa}$ diagnosis, and showed that fat intake (of course together with other factors, for example lymph node positive status and tumor stage) was associated with an increased risk of death. In fact, fat intake promotes oxidative stress, and inflammatory signaling, that as already said, are involved in BCa recurrence (127). An important meta-analysis of prospective studies was conducted by Bauer et al. in (157), and they found a modest inverse association between circulating 25-hydroxyvitamin D and $\mathrm{BCa}$ risk as concerning postmenopausal women, while apparently there was no association for younger women (157), Granulocyte macrophage colony-stimulating factor (GM-CSF) and matrix metalloproteinase 9 (MMP-9) play a central role in breast cancer and other tumors (158-163). They are produced by mesenchymal progenitor cells or adipose stem cells (ASC) and act together promoting the development and spread of cancer. In obese mice, the levels of GM-CSF increase and this triggers a mechanism that causes them to produce further GMCSF and MMP-9 (164). Together the two molecules make the breast cancer cells more aggressive, more prone to give rise to metastases and more active in turning off the response of 
the immune system against the tumor itself (164). This data suggests that the obese population has a higher risk of developing cancer due to obesity-associated adipose inflammation, which increase adipose secretion of pro-inflammatory factors like MMP and alter the tumor microenvironment $(165,166)$. A healthy diet associated with a correct prevention and a sports practice reduces cancer risk, attenuating adipose-related inflammatory mechanisms than can regulate cancer growth.

\section{OBESITY AND WOUND HEALING}

Obesity acts negatively on the wound healing both for local factors, as increased traction of the wound edges, fat necrosis, ease of bleeding, and infections, and for general factors possibly associated such as diabetes arteriosclerosis hypertension. Wound healing is a complex process that involves local, regional, and systemic response elements. Surprisingly, in spite of numerous reports of post-surgical complications including wound infection, delayed closure, dehiscence, hematoma, and seroma formation, pressure ulcers, and venous ulcers, little research has been conducted to investigate the mechanisms mediating obesity-related impaired wound healing. Artificial dermis has been used for the treatment of full-thickness burns and other areas regarding wound healing. Artificial dermis is composed of an inner collagen sponge layer that stimulates infiltration of the cells and an outer silicon membrane layer that prevents infection. When the artificial dermis is placed on skin defects, fibroblasts, and capillaries infiltrate into the pores of the collagen sponge. Then, the collagen sponge is spontaneously converted into regenerated connective tissue, so-called "dermis-like tissue." Recently, clinical effectiveness has been reported in combination therapy using artificial dermis and basic fibroblast growth factor. Artificial dermis, proposed by different companies and in particular PELNAC by Gunze is useful for reconstructing various full-thickness skin defect such as third-degree burns, giant nevi, traumas, and donor sites of skin flaps (167). It is also highly useful after resection of malignant skin tumors because it can reduce the sacrificial burden of skin grafts or flaps if extended surgery becomes necessary. Basic fibroblast growth factor (bFGF) is a cytokine that promotes granulation tissue formation and angiogenesis, and when used in combination with PELNAC produced excellent treatment outcomes even for wounds with a high risk of infection $(168,169)$. Several studies indicate that morbid obesity significantly increased the risk of a postoperative wound complication and infection. Obese women with breast cancer represent a unique patient population. They are at increased risk for the development of breast cancer and may experience more complications related to surgery and medical. Moreover, they may not be candidates for in breast reconstruction due to limited reconstructive options such as wound dehiscence and risk of reoperation following reconstruction (170). However, following surgery obese patients through the use of artificial dermis they should expect a better result without complications. Mendenhall et al. showed that the use of the dermal matrix in breast reconstruction produced an improvement in healing (171). In addition, obesity is the leading risk factor for type 2 diabetes (T2DM), and the risk of T2DM increases with increasing weight classes. Together, obesity and T2DM are risk factors for numerous comorbidities such as cardiovascular disease, gastrointestinal disorders, and osteoarthritis (172). One of the most common complications of diabetes is diabetic foot ulcer (173). Diabetic ulcers do not heal easily due to diabetic neuropathy and reduced blood flow, and non-healing ulcers may progress to gangrene, which necessitates amputation of the patient's foot. In an obese diabetic rat model, Kato et al. have developed a new therapy based on allogenic transplantation of an adipose-derived stem cell sheet combined with artificial skin, and show that it accelerates wound healing (174).

\section{CONCLUSION}

Excess weight is defined as secondary if it is a consequence of other diseases, such as hypothyroidism or other clearly identifiable causes. In the majority of cases it is instead primary because it is not caused by other diseases, but its development is favored by several factors that interact with each other. Obesity is known to be an important risk factor for cardiovascular disease and diabetes. Less known, but perhaps even more worrying, is the contribution this condition makes to the risk of developing certain cancers, particularly breast cancer. The excess of fat does not exclusively influence the correct and timely diagnosis of breast cancer but, by altering the tumor microenvironment, it can favor its growth, progression, response to therapies, consequently worsening the prognosis. The mechanisms underlying the cancer-obesity association are multiple and distinct for the different types of cancer. Obesity is certainly associated with a series of endocrine and metabolism alterations, in particular the metabolism of sex hormones, insulin, and Igf (insulin growth factor), adipokines (hormones produced by adipose tissue), as well as inflammation. There is strong evidence linking obesity to cancer, through the alteration of the metabolism of sex hormones and chronic inflammation. However, there is clear evidence that weight loss is able to positively influence all these mechanisms, probably by regulating the balance between cell proliferation and apoptosis. Based on the studies available to date, it can be concluded that paying attention to weight reduces the risk of developing most cancers. It seems obvious to talk about many causes at the origin of primary obesity, but still, to most of the overweight or obese subjects, only a diet is prescribed, to reduce the energy introduced every day. This approach is reductive because it must be considered that there are many risk factors of excess weight such as genetic factors, hormonal factors, a sedentary lifestyle, the environment, and eating behaviors that are often influenced by psychological aspects and not least the environment internal: the microbiota. More and more experimental evidence confirms that the microbiota affects body weight. Billions of microbes in the intestine contribute to determining the total weight of the organism, directly influencing the digestion and metabolism of the substrates introduced with 
the food as well as the quantity of sugars, fats, and proteins absorbed by the intestine. The future lines in the treatment of obesity seem to adopt as new strategies for weight loss, interventions on the microbiota.

\section{AUTHOR CONTRIBUTIONS}

MD contributed to the draft on breast cancer and obesity topics. FP, LQ, MCon, AS, and GS collected bibliographic data in order

\section{REFERENCES}

1. Pearce EN. Thyroid hormone and obesity. Curr Opin Endocrinol Diabetes Obes. (2012) 19:408-13. doi: 10.1097/MED.0b013e3 $28355 \mathrm{~cd} 6 \mathrm{c}$

2. Leeners B, Geary N, Tobler PN, Asarian L. Ovarian hormones and obesity. Hum Reprod Update. (2017) 23:300-21. doi: 10.1093/humupd/dmw045

3. Zhang ZY, Wang MW. Obesity, a health burden of a global nature. Acta Pharmacol Sin. (2012) 33:145-7. doi: 10.1038/aps.2011.185

4. Sturm R, An R, Maroba J, Patel D. The effects of obesity, smoking, and excessive alcohol intake on healthcare expenditure in a comprehensive medical scheme. S Afr Med J. (2013) 103:840-4. doi: 10.7196/SAMJ.7260

5. Ludwig DS, Peterson KE, Gortmaker SL. Relation between consumption of sugar-sweetened drinks and childhood obesity: a prospective, observational analysis. Lancet. (2001) 357:505-8. doi: 10.1016/S0140-6736(00)04041-1

6. Robinson TN. Television viewing and childhood obesity. Pediatr Clin North Am. (2001) 48:1017-25. doi: 10.1016/S0031-3955(05)70354-0

7. Scherer PE, Hill JA. Obesity, diabetes, and cardiovascular diseases: a compendium. Circ Res. (2016) 118:1703-5. doi: 10.1161/CIRCRESAHA.116.308999

8. Boccellino M, Di Domenico M, Donniacuo M, Bitti G, Gritti G, Ambrosio P, et al. AT1-receptor blockade: protective effects of irbesartan in cardiomyocytes under hypoxic stress. PLoS ONE. (2018) 13:e0202297. doi: 10.1371/journal.pone.0202297

9. Boccellino M, Di Stasio D, Romano A, Petruzzi M, Lucchese A, Serpico $\mathrm{R}$, et al. Lichen planus: molecular pathway and clinical implications in oral disorders. J Biol Regul Homeost Agents. (2018) 32:135-8.

10. Uzuncakmak TK, Akdeniz N, Karadag AS. Cutaneous manifestations of obesity and themetabolic syndrome. Clin Dermatol. (2018) 36:81-8. doi: 10.1016/j.clindermatol.2017.09.014

11. Menditti D, Laino L, Milano M, Caputo C, Boccellino M, D’Avino A, et al. Intraoral lymphoepithelial carcinoma of the minor salivary glands. In Vivo. (2012) 26:1087-9.

12. Hu Q, Peng J, Chen X, Li H, Song M, Cheng B, et al. Obesity and genes related to lipid metabolism predict poor survival in oral squamous cell carcinoma. Oral Oncol. (2019) 89:14-22. doi: 10.1016/j.oraloncology.2018. 12.006

13. Di Domenico M, Pierantoni GM, Feola A, Esposito F, Laino L, De Rosa A, et al. Prognostic significance of N-Cadherin expression in oral squamous cell carcinoma. Anticancer Res. (2011) 31:4211-8.

14. Pannone G, Santoro A, Feola A, Bufo P, Papagerakis P, Lo Muzio L, et al. The role of E-cadherin down-regulation in oral cancer: $\mathrm{CDH} 1$ gene expression and epigenetic blockage. Curr Cancer Drug Targets. (2014) 14:115-27. doi: 10.2174/1568009613666131126115012

15. Rajala MW, Scherer PE. Minireview: the adipocyte-at the crossroads of energy homeostasis, inflammation, and atherosclerosis. Endocrinology. (2003) 144:3765-73. doi: 10.1210/en.2003-0580

16. Ferroni P, Basili S, Falco A, Davi G. Oxidant stress and platelet activation in hypercholesterolemia. Antioxid Redox Signal. (2004) 6:747-56. doi: 10.1089/1523086041361587

17. Aquino G, Pannone G, Santoro A, Liguori G, Franco R, Serpico R, et al. pEGFR-Tyr 845 expression as prognostic factors in oral squamous cell carcinoma: a tissue-microarray study with clinic-pathological correlations. Cancer Biol Ther. (2012) 13:967-77. doi: 10.4161/cbt.20991 to develop the written manuscript regarding oxidative stress. $\mathrm{AR}, \mathrm{MCop}, \mathrm{KF}$, and AB-F organized a data collection on gut hormones. GN and GF contributed to the wound healing and obesity. $\mathrm{MB}$ revised all the manuscript.

\section{ACKNOWLEDGMENTS}

We thank the company Gunze for their support in copyediting this review.

18. Di Zazzo E, Feola A, Zuchegna C, Romano A, Donini CF, Bartollino S, et al. The p 85 regulatory subunit of PI3K mediates CAMP-PKA and insulin biological effects on MCF-7 cell growth and motility. Sci World J. (2014) 2014:565839. doi: 10.1155/2014/565839

19. Leibel RL. The role of leptin in the control of body weight. Nutr. Rev. (2002) 60:S15-9. doi: 10.1301/002966402320634788

20. Friedman JM. The function of leptin in nutrition, weight, and physiology. Nutr. Rev. (2002) 60:S1-14. doi: 10.1301/002966402320634878

21. Rondinone CM. Adipocyte-derived hormones, cytokines, and mediators. Endocrine. (2006) 29:81-90. doi: 10.1385/ENDO:29:1:81

22. Briet M, Schiffrin EL. The role of aldosterone in the metabolic syndrome. Curr Hypertens Rep. (2011) 13:163-72. doi: 10.1007/s11906-011-0182-2

23. Zhang Y, Proenca R, Maffei M, Barone M, Leopold L, Friedman JM. Positional cloning of the mouse obese gene and its human homologue. Nature. (1994) 372:425-32. doi: 10.1038/372425a0

24. Elmquist JK. Hypothalamic pathways underlying the endocrine, autonomic, and behavioural effects of leptin. Physiol Behav. (2001) 74:703-8. doi: 10.1016/S0031-9384(01)00613-8

25. Fruhbeck G, Aguado M, Martinez JA. In vitro lipolytic effect of leptin on mouse adipocytes: evidence for a possible autocrine/paracrine role of leptin. Biochem Biophys Res Commun. (1997) 240:590-4. doi: 10.1006/bbrc.1997.7716

26. Dobbins RL, Szczepaniak LS, Zhang W, McGarry JD. Chemical sympathectomy alters regulation of body weight during prolonged ICV leptin infusion. Am J Physiol Endocrinol Metab. (2003) 284:E778-87. doi: 10.1152/ajpendo.00128.2002

27. Vincent HK, Taylor AG. Biomarkers and potential mechanisms of obesity-induced oxidant stress in humans. Int J Obes. (2006) 30:400-18. doi: 10.1038/sj.ijo.0803177

28. Vanacore D, Messina G, Lama S, Bitti G, Ambrosio P, Tenore GC, et al. Effect of restriction vegan diet's on muscle mass, oxidative status and myocytes differentiation: a pilot study. J Cell Physiol. (2018) 233:9345-53. doi: $10.1002 /$ jcp. 26427

29. Martineau LC, Couture A, Spoor D, Benhaddou-Andaloussi A, Harris C, Meddah B, et al. Anti-diabetic properties of the Canadian lowbush blueberry Vaccinium angustifolium Ait. Phytomedicine. (2006) 13:612-23. doi: 10.1016/j.phymed.2006.08.005

30. Sakaida H, Nagao K, Higa K, Shirouchi B, Inoue N, Hidaka F, et al. Effect of Vaccinium ashei reade leaves on angiotensin converting enzyme activity in vitro and on systolic blood pressure of spontaneously hypertensive rats in vivo. Biosci Biotechnol Biochem. (2007) 71:2335-7. doi: 10.1271/bbb.70277

31. Inoue $\mathrm{N}$, Nagao $\mathrm{K}$, Nomura $\mathrm{S}$, Shirouchi B, Inafuku M, Hirabaru $H$, et al. Effect of Vaccinium ashei reade leaf extracts on lipid metabolism in obese OLETF rats. Biosci Biotechnol Biochem. (2011) 75 :2304-8. doi: 10.1271/bbb.110451

32. Boccellino M, Giuberti G, Quagliuolo L, Marra M, D’Alessandro AM, Fujita $\mathrm{H}$, et al. Apoptosis induced by interferon-alpha and antagonized by EGF is regulated by caspase-3-mediated cleavage of gelsolin in human epidermoid cancer cells. J Cell Physiol. (2004) 201:71-83. doi: 10.1002/jcp.20058

33. Boccellino M, Camussi G, Giovane A, Ferro L, Calderaro V, Balestrieri C, et al. (2005).Platelet-activating factor regulates cadherin-catenin adhesion system expression and beta-catenin phosphorylation during Kaposi's sarcoma cell motility. Am J Pathol. 166:1515-22. doi: 10.1016/S0002-9440(10)62367-X 
34. Chien J, Ota T, Aletti G, Shridhar R, Boccellino M, Quagliuolo L, et al. Serine protease HtrAl associates with microtubules and inhibits cell migration. $\mathrm{Mol}$ Cell Biol. (2009) 29:4177-87. doi: 10.1128/MCB.00035-09

35. Baldi A, Piccolo MT, Boccellino MR, Donizetti A, Cardillo I, La Porta R, et al. Apoptosis induced by piroxicam plus cisplatin combined treatment is triggered by p21 in mesothelioma. PLoS ONE. (2011) 6:e23569. doi: 10.1371/journal.pone.0023569

36. Boccellino M, La Porta R, Coppola M, Petronella P, Freda F, Calderaro V, et al. Peritoneal dialysis fluid activates calcium signaling and apoptosis in mesothelial cells. Apoptosis. (2013) 18:43-56. doi: 10.1007/s10495-012-0771-9

37. Włodarczyk M, Nowicka G. Obesity, DNA damage, and development of obesity-related diseases. Int J Mol Sci. (2019) 20:1146. doi: 10.3390/ijms20051146

38. Romano M, De Francesco F, Pirozzi G, Gringeri E, Boetto R, Di Domenico $\mathrm{M}$, et al. Expression of cancer stem cell biomarkers as a tool for a correct therapeutic approach to hepatocellular carcinoma. Oncoscience. (2015) 2:443-56. doi: 10.18632/oncoscience.163

39. Romano M, De Francesco F, Gringeri E, Giordano A, Ferraro GA, Di Domenico $\mathrm{M}$, et al. Tumor microenvironment versus cancer stem cells in cholangiocarcinoma: synergistic effects? J Cell Physiol. (2016) 231:768-76. doi: $10.1002 /$ jcp.25190

40. Rizzo A, Di Domenico M, Carratelli CR, Mazzola N, Paolillo R. Induction of proinflammatory cytokines in human osteoblastic cells by Chlamydia pneumoniae. Cytokine. (2011) 56:450-7. doi: 10.1016/j.cyto.2011.06.027

41. Koliaki C, Szendroedi J, Kaul K, Jelenik T, Nowotny P, Jankowiak F, et al. Adaptation of hepatic mitochondrial function in humans with nonalcoholic fatty liver is lost in steatohepatitis. Cell Metab. (2015) 21:739-46. doi: 10.1016/j.cmet.2015.04.004

42. Fridlyand LE, Philipson LH. Oxidative reactive species in cell injury: mechanisms in diabetes mellitus and therapeutic approaches. Ann N Y Acad Sci. (2005) 1066:136-51. doi: 10.1196/annals.1363.019

43. Keaney JF Jr, Larson MG, Vasan R, Wilson PWF, Lipinska I, Corey D, et al. Obesity and systemic oxidative stress: clinical correlates of oxidative stress in the Framingham Study. Arterioscler Thromb Vasc Biol. (2003) 23:434-9. doi: 10.1161/01.ATV.0000058402.34138.11

44. Furukawa S, Fujita T, Shimabukuro M, Iwaki M, Yamada Y, Nakajima Y, et al. Increased oxidative stress in obesity and its impact on metabolic syndrome. J Clin Invest. (2004) 114:1752-61. doi: 10.1172/JCI200421625

45. Karaouzene N, Merzouk H, Aribi M, Merzouk SA, Berrouiguet AY, Tessier $\mathrm{C}$, et al. Effects of the association of aging and obesity on lipids, lipoproteins and oxidative stress biomarkers: a comparison of older with young men. Nutr Metab Cardiovasc Dis. (2011) 21:792-9. doi: 10.1016/j.numecd.2010.02.007

46. D’Angelo S, La Porta R, Napolitano M, Galletti P, Quagliuolo L, Boccellino M. Effect of Annurca apple polyphenols on human HaCaT keratinocytes proliferation. J Med Food. (2012) 15:1024-31. doi: 10.1089/jmf.2012.0076

47. Ramezanipour M, Jalali M, Sadrzade-Yeganeh H, Keshavarz SA, Eshraghian MR, Bagheri M, et al. The effect of weight reduction on antioxidant enzymes and their association with dietary intake of vitamins A, C and E. Arq Bras Endocrinol Metabol. (2014) 58:744-9. doi: 10.1590/0004-2730000003206

48. Tatullo M, Marrelli M, Scacco S, Lorusso M, Doria S, Sabatini R, et al. Relationship between oxidative stress and "burning mouth syndrome" in female patients: a scientific hypothesis. Eur Rev Med Pharmacol Sci. (2012) 16:1218-21.

49. Ricci S, Pinto F, Auletta A, Giordano A, Giovane A, Settembre G, et al. The enigmatic role of matrix metalloproteinases in epithelial-to-mesenchymal transition of oral squamous cell carcinoma: Implications and nutraceutical aspects. J Cell Biochem. (2019) 120:6813-9. doi: 10.1002/jcb.26905

50. Miyazaki N, Yamaguchi O, Nomiya M, Aikawa K, Kimura J. Preventive effect of hydrogen water on the development of detrusor overactivity in a rat model of bladder outlet obstruction. J Urol. (2016) 195:780-7. doi: 10.1016/j.juro.2015.10.117

51. Yasuyoshi M, Tomohiro M, Kensuke M, Akihiro A, Kojiro O, Hideki S. A review of oxidative stress and urinary dysfunction caused by bladder outlet obstruction and treatments using antioxidants. Antioxidants. (2019) 8:132. doi: $10.3390 /$ antiox 8050132

52. Salim S. Oxidative stress and the central nervous system. J Pharmacol Exp Ther. (2017) 360:201-5. doi: 10.1124/jpet.116.237503
53. Pedata P, Boccellino M, La Porta R, Napolitano M, Minutolo P, Sgro LA, et al. Interaction between combustion-generated organic nanoparticles and biological systems: in vitro study of cell toxicity and apoptosis in human keratinocytes. Nanotoxicology. (2012) 6:338-52. doi: 10.3109/17435390.2011.579630

54. Borghese C, Casagrande N, Pivetta E, Colombatti A, Boccellino M, Amler E, et al. Self-assembling nanoparticles encapsulating zoledronic acid inhibit mesenchymal stromal cells differentiation, migration and secretion of proangiogenic factors and their interactions with prostate cancer cells. Oncotarget. (2017) 8:42926-38. doi: 10.18632/oncotarget.17216

55. Di Domenico M, Pozzi D, Palchetti S, Digiacomo L, Iorio R, Astarita C, et al. Nanoparticle-biomolecular corona: a new approach for the early detection of non-small-cell lung cancer. J Cell Physiol. (2019) 234:9378-86. doi: $10.1002 / j$ cp. 27622

56. Canoy D, Wareham N, Welch A, Bingham S, Luben R, Day N, et al. Plasma ascorbic acid concentrations and fat distribution in 19068 British men and women in the European Prospective Investigation into Cancer and Nutrition Norfolk cohort study. Am J Clin Nutr. (2005) 82:1203-9. doi: 10.1093/ajcn/82.6.1203

57. Snijder MB, van Dam RM, Visser M, Deeg DJ, Dekker JM, Bouter LM, et al. Adiposity in relation to vitamin D status and parathyroid hormone levels: a population-based study in older men and women. J Clin Endocrinol Metab. (2005) 90:4119-23. doi: 10.1210/jc.2005-0216

58. Kimmons JE, Blanck HM, Tohill BC, Zhang J, Khan LK. Associations between body mass index and the prevalence of low micronutrient levels among US adults. Med Gen Med. (2006) 8:59.

59. Rai MF, Sandell LJ. Inflammatory mediators: tracing links between obesity and osteoarthritis. Crit Rev Eukaryot Gene Expr. (2011) 21:131-42. doi: 10.1615/CritRevEukarGeneExpr.v21.i2.30

60. Kuo FC, Huang YH, Lin FH, Hung YJ, Hsieh $\mathrm{CH}, \mathrm{Lu} \mathrm{CH}$, et al. Circulating Soluble IL-6 Receptor Concentration and Visceral Adipocyte Size Are Related to Insulin Resistance in aiwanese Adults with Morbid Obesity. Metab Syndr Relat Disord. (2017) 15:187-93. doi: 10.1089/met.2016. 0135

61. Liu Y, Kongsuphol P, Gourikutty SB, Ramadan Q. Human adipocyte differentiation and characterization in a perfusion-based cell culture device. Biomed Microdevices. (2017) 19:18. doi: 10.1007/s10544-017-0164-5

62. Beltowski J, Wojcicka G, Jamroz A. Leptin decreases plasma paraoxonase 1 (PON1) activity and induces oxidative stress: The possible novel mechanism for proatherogenic effect of chronic hyperleptinemia. Atherosclerosis. (2003) 170:21-9. doi: 10.1016/S0021-9150(03)00236-3

63. Fortuño A, Bidegain J, Baltanás A, Moreno M, Montero L, Landecho $\mathrm{MF}$, et al. Is leptin involved in phagocytic NADPH oxidase overactivity in obesity? Potential clinical implications. J Hypertens. (2010) 28:1944-50. doi: 10.1097/HJH.0b013e32833c21af

64. Vincent HK, Vincent KR, Bourguignon C, Braith RW. Obesity and postexercise oxidative stress in older women. Med Sci Sports Exerc. (2005) 37:213-9. doi: 10.1249/01.MSS.0000152705.77073.B3

65. Prasenjit M, Jain SK. Obesity, oxidative stress, adipose tissue dysfunction, and the associated health risks: causes and therapeutic strategies. Metab Syndr Related Disord. (2015) 13: 423-44. doi: 10.1089/met.2015. 0095

66. Dandona P, Kumar V, Aljada A, Ghanim H, Syed T, Hofmayer D, et al. Angiotensin II receptor blocker valsartan suppresses reactive oxygen species generation in leukocytes, nuclear factor-kappa B, in mononuclear cells of normal subjects: Evidence of an antiinflammatory action. J Clin Endocrinol Metab. (2003) 88:4496-501. doi: 10.1210/jc.2002-021836

67. Toldo S, Boccellino M, Rinaldi B, Seropian IM, Mezzaroma E, Severino A, et al. Altered oxido-reductive state in the diabetic heart: loss of cardioprotection due to protein disulfide isomerase. Mol Med. (2011) 7:1012-21. doi: 10.2119/molmed.2011.00100

68. Bournat JC, Brown CW. Mitochondrial dysfunction in obesity. Curr Opin Endocrinol Diabetes Obes. (2010) 17:446-52. doi: 10.1097/MED.0b013e32833c3026

69. Gao CL, Zhu C, Zhao YP, Chen XH, Ji CB, Zhang CM, et al. Mitochondrial dysfunction is induced by high levels of glucose and free fatty acids in 3T3-L1 adipocytes. Mol Cell Endocrinol. (2010) 320:25-33. doi: 10.1016/j.mce.2010.01.039 
70. Vincent HK, Bourguignon CM, Taylor AG. Relationship of the dietary phytochemical index to weight gain, oxidative stress and inflammation in overweight young adults. J Hum Nutr Diet. (2010) 23:20-9. doi: 10.1111/j.1365-277X.2009.00987.x

71. Alevizaki M, Saltiki K, Voidonikola P, Mantzou E, Papamichael C, Stamatelopoulos K. Free thyroxine is an independent predictor of subcutaneous fat in euthyroid individuals. Eur J Endocrinol. (2009) 16:45965. doi: 10.1530/EJE-09-0441

72. Cheserek MJ, Wu G, Shen L, Shi Y, Le G. Evaluation of the relationship between subclinical hypothyroidism and metabolic syndrome components among workers. Int J Occup Med Environ Health. (2014) 27:175-87. doi: 10.2478/s13382-014-0240-5

73. Buerba R, Roman SA, Sosa JA. Thyroidectomy and parathyroidectomy in patients with high body mass index are safe overall: analysis of 26864 patients. Surgery. (2011) 150:950-8. doi: 10.1016/j.surg.2011.02.017

74. Jonklaas J, Nsouli-Maktabi H. Weight changes in euthyroid patients under and going thyroidectomy. Thyroid. (2011) 21:1343-51. doi: 10.1089/thy.2011.0054

75. Weinreb JT, Yang Y, Braunstein GD. Do patients gain weight after thyroidectomy for thyroid cancer? Thyroid. (2011) 21:1339-42. doi: $10.1089 /$ thy.2010.0393

76. Prats-Puig A, Sitjar C, Ribot R, Calvo M, Clausell-Pomés N, Soler-Roca $\mathrm{M}$, et al. Relative hypoadiponectinemia, insulin resistance, and increased visceral fat in euthyroid prepubertal girls with low normal serum free thyroxine. Obesity. (2011) 20:1455-61. doi: 10.1038/oby.2011.206

77. Lu S, Guan Q, Liu Y, Wang H, Xu W, Li X, et al. Role of extrathyroidal TSHR expression in adipocyte differentiation and its association with obesity. Lipids Health Dis. (2012) 11:17. doi: 10.1186/1476-511X-11-17

78. Ortega FJ, Moreno-Navarrete JM, Ribas V, Esteve E, Rodriguez-Hermosa JI, Ruiz B, et al. Subcutaneous fat shows higher thyroid hormone receptoralpha1 gene expression than omental fat. Obesity. (2009) 17:2134-41. doi: 10.1038/oby.2009.110

79. Emerson CH. Anthropomorphic thyroidopathies? Thyroid. (2010) 20:11957. doi: 10.1089/thy.2010.1665

80. Reinehr T. Obesity and thyroid function. Mol Cell Endocrinol. (2010) 316:165-71. doi: 10.1016/j.mce.2009.06.005

81. Amin A, Dhillo WS, Murphy KG. The central effects of thyroid hormones on appetite. J Thyroid Res. (2011) 2011:306510. doi: 10.4061/2011/306510

82. Araujo RL, Carvalho DP. Bioenergetic impact of tissue-specific regulation of iodothyronine deiodinases during nutritional imbalance. J Bioenerg Biomembr. (2011) 43:59-65. doi: 10.1007/s10863-011-9327-x

83. Vella KR, Ramadoss P, Lam FS, Harris JC, Ye FD, Same PD, et al. NPY and MC4R signaling regulate thyroid hormone levels during fasting through both central and peripheral pathways. Cell Metab. (2011) 14:780-90. doi: 10.1016/j.cmet.2011.10.009

84. Adrian TE, Ferri GL, Bacarese-Hamilton AJ, Fuessl HS, Polak JM, Bloom SR. Human distribution and release of a putative new gut hormone, peptide YY. Gastroenterology. (1985) 89:1070-7. doi: 10.1016/0016-5085(85)90211-2

85. Kiela PR, Ghishan FK. Physiology of intestinal absorption and secretion. Best Pract Res Clin Gastroenterol. (2016) 30:145-59. doi: 10.1016/j.bpg.2016.02.007

86. Oesch S, Ruegg C, Fischer B, Degen L, Beglinger C. Effect of gastric distension prior to eating on food intake and feelings of satiety in humans. Physiol Behav. (2006) 87:903-10. doi: 10.1016/j.physbeh.2006. 02.003

87. Drucker DJ. Glucagon-like peptides: regulators of cell proliferation, differentiation, and apoptosis. Mol Endocrinol. (2003) 17:161-71. doi: 10.1210/me.2002-0306

88. Neary NM, Small CJ, Druce MR, Park AJ, Ellis SM, Semjonous NM, et al. Peptide YY3-36 and glucagon-like peptide-17-36 inhibit food intake additively. Endocrinology. (2005) 146:5120-7. doi: 10.1210/en.2005-0237

89. Baggio LL, Drucker DJ. Biology of incretins: GLP-1 and GIP. Gastroenterology. (2007) 132:2131-57. doi: 10.1053/j.gastro.2007.03.054

90. Le Roux CW, Aylwin SJ, Batterham RL, Borg CM, Coyle F, Prasad $\mathrm{V}$, et al. Gut hormone profiles following bariatric surgery favor an anorectic state, facilitate weight loss, and improve metabolic parameters. Ann Surg. (2006) 243:108-14. doi: 10.1097/01.sla.0000183349. 16877.84
91. Bueter M, Ashrafian H, le Roux CW. Mechanisms of weight loss after gastric bypass and gastric banding. Obes Facts. (2009) 2:325-31. doi: $10.1159 / 000232383$

92. Bueter M, le Roux CW. Gastrointestinal hormones, energy balance and bariatric surgery. Int J Obes. (2011) 35:S35-9. doi: 10.1038/ijo.2011.146

93. Batterham RL, Cowley MA, Small CJ, Herzog H, Cohen MA, Dakin CL, et al. Gut hormone PYY3-36 physiologically inhibits food intake. Nature. (2002) 418:650-4. doi: 10.1038/nature00887

94. Pittner RA, Moore CX, Bhavsar SP, Gedulin BR, Smith PA, Jodka CM, et al. Effects of PYY3-36 in rodent models of diabetes and obesity. Int J Obes Relat Metab Disord. (2004) 28:963-71. doi: 10.1038/sj.ijo.0802696

95. Sloth B, Holst JJ, Flint A, Gregersen NT, Astrup A. Effects of PYY1- 36 and PYY3-36 on appetite, energy intake, energy expenditure, glucose and fat metabolism in obese and lean subjects. Am J Physiol Endocrinol Metab. (2007) 292:E1062-8. doi: 10.1152/ajpendo.00450.2006

96. van den Hoek AM, Heijboer AC, Corssmit EP, Voshol PJ, Romijn JA, Havekes LM, et al. PYY3-36 reinforces insulin action on glucose disposal in mice fed a high-fat diet. Diabetes. (2004) 53:1949-52. doi: 10.2337/diabetes.53.8.1949

97. Federico A, Dallio M, Di Sarno R, Giorgio V, Miele L. Gut microbiota, obesity and metabolic disorders. Minerva Gastroenterol Dietol. (2017) 63:337-44. doi: 10.23736/S1121-421X.17.02376-5

98. Marsh PD, Do T, Beighton D, Devine DA. Influence of saliva on the oral microbiota. Periodontol. (2000) 70:80-92. doi: 10.1111/prd.12098

99. Boccellino M, Di Stasio D, Serpico R, Lucchese A, Guida A, Settembre G, et al. Analysis of saliva samples in patients with Prader-Willi syndrome. $J$ Biol Regul Homeost Agents. (2018) 32:107-11.

100. Yang BG, Hur KY, Lee MS. Alterations in gut microbiota and immunity by dietary fat. Yonsei Med J. (2017) 58:1083-91. doi: $10.3349 /$ ymj.2017.58.6.1083

101. Dao MC, Clément K. Gut microbiota and obesity: Concepts relevant to clinical care. Eur J Intern Med. (2018) 48:18-24. doi: 10.1016/j.ejim.2017.10.005

102. Dlugosz A, Muschiol S, Zakikhany K, Assadi G, D'Amato M, Lindberg G. Human enteroendocrine cell responses to infection with Chlamydia trachomatis: a microarray study. Gut Pathog. (2014) 6:24. doi: 10.1186/1757-4749-6-24

103. Rizzo A, Pallone F, Monteleone G, Fantini MC. Intestinal inflammation and colorectal cancer: a double-edged sword? World J Gastroenterol. (2011) 17:3092-100. doi: 10.3748/wjg.v17.i26.3092

104. Kawamoto S, Maruya M, Kato LM, Suda W, Atarashi K, Doi Y, et al. Foxp3(+) $\mathrm{T}$ cells regulate immunoglobulin a selection and facilitate diversification of bacterial species responsible for immune homeostasis. Immunity. (2014) 41:152-65. doi: 10.1016/j.immuni.2014.05.016

105. Dohan Ehrenfest DM, Del Corso M, Inchingolo F, Sammartino G, Charrier JB. Platelet-rich plasma (PRP) and platelet-rich fibrin (PRF) in human cell cultures: growth factor release and contradictory results. Oral Surg Oral Med Oral Pathol Oral Radiol Endod. (2010) 110:418-21. doi: 10.1016/j.tripleo.2010.05.059

106. Dohan Ehrenfest DM, Lemo N, Jimbo R, and Sammartino G. Selecting a relevant animal model for testing the in vivo effects of Choukroun's plateletrich fibrin (PRF): rabbit tricks and traps. Oral Surg Oral Med Oral Pathol Oral Radiol Endod. (2010) 110:413-6. doi: 10.1016/j.tripleo.2010.05.057

107. Rizzo A, Losacco A, Carratelli CR, Domenico MD, Bevilacqua N. Lactobacillus plantarum reduces Streptococcus pyogenes virulence by modulating the IL-17, IL-23 and Toll-like receptor $2 / 4$ expressions in human epithelial cells. Int Immunopharmacol. (2013) 17:453-61. doi: 10.1016/j.intimp.2013.07.005

108. Gribble FM, Reimann F. Function and mechanisms of enteroendocrine cells and gut hormones in metabolism. Nat. Rev. Endocrinol. (2019) 15: 226-37. doi: 10.1038/s41574-019-0168-8

109. Gérard P. Gut microbiota and obesity. Cell Mol Life Sci. (2016) 73:147-62. doi: 10.1007/s00018-015-2061-5

110. de Clercq NC, Groen AK, Romijn JA, Nieuwdorp M. Microbiota in obesity and undernutrition. Adv Nutr. (2016) 7:1080-9. doi: 10.3945/an.116.012914

111. Torres-Fuentes C, Schellekens H, Dinan TG, Cryan JF. The microbiotagut-brain axis in obesity. Lancet Gastroenterol Hepatol. (2017) 2:747-56. doi: 10.1016/S2468-1253(17)30147-4 
112. Saad MJ, Santos A, Prada PO. Linking gut microbiota and inflammation to obesity and insulin resistance. Physiology. (2016) 31:283-93. doi: 10.1152/physiol.00041.2015

113. Isolauri E. Microbiota and Obesity. Nestle Nutr Inst Workshop Ser. (2017) 88:95-105. doi: 10.1159/000455217

114. Patterson E, Ryan PM, Cryan J, Dinan TG, Ross RP, Fitzgerald GF, et al. Gut microbiota, obesity and diabetes. Postgrad Med J. (2016) 92:286-300. doi: 10.1136/postgradmedj-2015-133285

115. Brahe LK, Astrup A, Larsen LH. Can we prevent obesity-related metabolic diseases by dietary modulation of the gut microbiota? Adv Nutr. (2016) 15;7:90-101. doi: 10.3945/an.115.010587

116. Baothman OA, Zamzami MA, Taher I, Abubaker J, Abu-Farha M. The role of Gut Microbiota in the development of obesity and diabetes. Lipids Health Dis. (2016) 18:15-108. doi: 10.1186/s12944-016-0278-4

117. Ferlay J, Shin HR, Bray F, Forman D, Mathers C, Parkin DM. Estimates of worldwide burden of cancer in 2008: GLOBOCAN 2008. Int J Cancer. (2010) 127:2893-917. doi: 10.1002/ijc.25516

118. Di Domenico M, Santoro A, Ricciardi C, Iaccarino M, Iaccarino S, Freda $\mathrm{M}$, et al. Epigenetic fingerprint in endometrial carcinogenesis: the hypothesis of a uterine field cancerization. Cancer Biol Ther. (2011). 12:447-57. doi: $10.4161 /$ cbt.12.5.15963

119. Narod SA. Breast cancer in young women. Nat Rev Clin Oncol. (2012) 9:460-70. doi: 10.1038/nrclinonc.2012.102

120. Boccellino M, Alaia C, Misso G, Cossu AM, Facchini G, Piscitelli R, et al. Gene interference strategies as a new tool for the treatment of prostate cancer. Endocrine. (2015) 49:588-605. doi: 10.1007/s12020-015-0629-3

121. Boccellino M, Vanacore D, Zappavigna S, Cavaliere C, Rossetti S, D’Aniello C, et al. Testicular cancer from diagnosis to epigenetic factors. Oncotarget. (2017) 8:104654-63. doi: 10.18632/oncotarget.20992

122. Giudice A, Montella M, Boccellino M, Crispo A, D'Arena G, Bimonte $S$, et al. Epigenetic changes induced by green tea catechins are associated with prostate cancer. Curr. Mol. Med. (2017) 17:405-20. doi: 10.2174/1566524018666171219101937

123. Saberi-Karimian M, Katsiki N, Caraglia M, Boccellino M, Majeed M, Sahebkar A. Vascular endothelial growth factor: An important molecular target of curcumin. Crit Rev Food Sci Nutr. (2017) 30:1-14. doi: 10.1080/10408398.2017.1366892

124. Auricchio F, Migliaccio A, Castoria G, Rotondi A, Di Domenico M, Pagano M. Activation-inactivation of hormone binding sites of the oestradiol-17 beta receptor is a multiregulated process. J Steroid Biochem. (1986) 24:39-43. doi: 10.1016/0022-4731(86)90029-4

125. Auricchio F, Migliaccio A, Castoria G, Rotondi A, Di Domenico M. Calmodulin-stimulated estradiol receptor-tyrosine kinase. Methods Enzymol. (1987) 139:731-44. doi: 10.1016/0076-6879(87)39123-2

126. Migliaccio A, Castoria G, de Falco A, Di Domenico M, Galdiero M, Nola $\mathrm{E}$, et al. In vitro phosphorylation and hormone binding activation of the synthetic wild type human estradiol receptor. J Steroid Biochem Mol Biol. (1991) 38:407-13. doi: 10.1016/0960-0760(91)90328-3

127. Brenner DR, Brockton NT, Kotsopulos J, Cotterchio M, Boucher BA, Courneya KS, et al. Breast cancer survival among young women: a review of the role of modifiable lifestyle factors. Cancer Causes Control. (2016) 27: 459-72. doi: 10.1007/s10552-016-0726-5

128. Fiorelli A, Ricciardi C, Pannone G, Santoro A, Bufo P, Santini M, et al. Interplay between steroid receptors and neoplastic progression in sarcoma tumors. J Cell Physiol. (2011) 226:2997-3003. doi: 10.1002/jcp.22645

129. Brown KA, Simpson ER. Obesity and breast cancer: mechanisms and therapeutic implications. Front Biosci. (2012) 4:2515-24. doi: 10.2741/e562

130. Castoria G, Migliaccio A, D'Amato L, Di Stasio R, Ciociola A, Lombardi $\mathrm{M}$, et al. Integrating signals between cAMP and MAPK pathways in breast cancer. Front Biosci. (2008) 13:1318-27. doi: 10.2741/2764

131. Zahid H, Simpsonand ER, Brown KA. Inflammation, dysregulated metabolism and aromatase in obesity and breast cancer. Curr. Opin. Pharmacol. (2016) 31:90-6. doi: 10.1016/j.coph.2016.11.003

132. Di Domenico M, Giordano A. Signal transduction growth factors: the effective governance of transcription and cellular adhesion in cancer invasion. Oncotarget. (2017) 8:36869-84. doi: 10.18632/oncotarget.16300

133. Spugnini EP, Cardillo I, Fanciulli M, Crispi S, Vincenzi B, Boccellino M, et al. Electroporation as a strategy to promote HtrAl gene uptake and chemotherapy efficacy in a mouse model of mesothelioma. Front Biosci. (2013) 5:974-81. doi: 10.2741/E677

134. Spugnini EP, Melillo A, Quagliuolo L, Boccellino M, Vincenzi B, Pasquali P, et al. Definition of novel electrochemotherapy parameters and validation of their in vitro and in vivo effectiveness. J Cell Physiol. (2014) 229:1177-81. doi: $10.1002 /$ jcp. 24548

135. Boccellino M, Quagliuolo L, Alaia C, Grimaldi A, Addeo R, Nicoletti GF, et al. The strange connection between epidermal growth factor receptor tyrosine kinase inhibitors and dapsone: from rash mitigation to the increase in anti-tumor activity. Curr Med Res Opin. (2016) 32:1839-48. doi: 10.1080/03007995.2016.1211522

136. Feola A, Ricci S, Kouidhi S, Rizzo A, Penon A, Formisano P, et al. Multifaceted breast cancer: the molecular connection with obesity. J Cell Physiol. (2017) 232:69-77. doi: 10.1002/jcp.25475

137. Wichtowski M, Murawa D, Kulcenty K, Zaleska K. Electrochemotherapy in breast cancer - discussion of the method and literature review. Breast Care. (2017) 12:409-14. doi: 10.1159/000479954

138. Mannell A. An overview of risk factors for recurrent breast cancer. S Afr J Surg. (2017) 55:29-34.

139. Sabol RA, Bowles AC, Côté A, Wise R, O’Donnell B, Matossian MD, et al. Leptin produced by obesity-altered adipose stem cells promotes metastasis but not tumorigenesis of triple-negative breast cancer in orthotopic xenograft and patient-derived xenograft models. Breast Cancer Res. (2019) 21:67. doi: 10.1186/s13058-019-1153-9

140. Lamberti M, Capasso R, Lombardi A, Di Domenico M, Fiorelli A, Feola A, et al. Two different serum MiRNA signatures correlate with the clinical outcome and histological subtype in pleural malignant mesothelioma patients. PLoS ONE. (2015) 10:e0135331. doi: 10.1371/journal.pone. 0135331

141. Vanacore D, Boccellino M, Rossetti S, Cavaliere C, D’Aniello C, Di Franco $\mathrm{R}$, et al. Micrornas in prostate cancer: an overview. Oncotarget. (2017) 8:50240-51. doi: 10.18632/oncotarget.16933

142. Law JH, Habibi G, Hu K, Masoudi H, Wang MYC, Stratford AL, et al. Phosphorylated insulin-like growth factor-i/insulin receptor is present in all breast cancer subtypes and is related to poor survival. Cancer Res. (2008) 68:10238-46. doi: 10.1158/0008-5472.CAN-08-2755

143. Auricchio F, Di Domenico M, Migliaccio A, Castoria G, Bilancio A. The role of estradiol receptor in the proliferative activity of vanadate on MCF-7 cells. Cell Growth Differ. (1995) 6:105-13.

144. Fiorelli A, Vicidomini G, Di Domenico M, Napolitano F, Messina G, Morgillo F, et al. Vascular endothelial growth factor in pleural fluid for differential diagnosis of benign and malignant origin and its clinical applications. Interact Cardiovasc Thorac Surg. (2011) 12:420-4. doi: 10.1510/icvts.2010.250357

145. Di Domenico M, D’apuzzo F, Feola A, Cito L, Monsurrò A, Pierantoni GM, et al. Cytokines and VEGF induction in orthodontic movement in animal models. J Biomed Biotechnol. (2012) 2012:201689. doi: 10.1155/2012/201689

146. Rodrigues Dos Santos C, Fonseca I, Dias S, Mendes de Almeida JC. Plasma level of LDL-cholesterol at diagnosis is a predictor factor of breast tumor progression. BMC Cancer. (2014) 14:132. doi: 10.1186/1471-2407-14-132

147. Molfino A, Amabile MI, Monti M, Arcieri S, Rossi Fanelli F, Muscaritoli M. The role of docosahexaenoic acid (DHA) in the control of obesity and metabolic derangements in breast cancer. Int J Mol Sci. (2016) 17:505. doi: 10.3390/ijms17040505

148. Fiorelli A, Accardo M, Carelli E, Angioletti D, Santini M, Di Domenico M. Circulating tumor cells in diagnosing lung cancer: clinical and morphologic analysis. Ann Thorac Surg. (2015) 99:1899-905. doi: 10.1016/j.athoracsur.2014.11.049

149. Fiorelli A, Ricci S, Feola A, Mazzella A, D’Angelo L, Santini M, et al. Matrix metalloproteinase -9 and tissue inhibitor of metalloproteinase -1 in diagnosis of pleural effusion of malignant origin. Interact Cardiovasc Thorac Surg. (2016) 22:411-8. doi: 10.1093/icvts/ivv378

150. Sapienza C, Issa JP. Diet, nutrition, and cancer epigenetics. Annu Rev Nutr. (2016) 36:665-81. doi: 10.1146/annurev-nutr-121415112634

151. Imayama I, Ulrich CM, Alfano CM, Wang C, Xiao L, Wener MH, et al. Effects of a caloric restriction weight loss diet and exercise on inflammatory biomarkers in overweight/obese postmenopausal 
women: a randomized controlled trial. Cancer Res. (2012) 72:2314-26. doi: 10.1158/0008-5472.CAN-11-3092

152. Selvin E, Paynter NP, Erlinger TP. The effect of weight loss on Creactive protein: a systematic review. Arch Intern Med. (2007) 167:31-9. doi: $10.1001 /$ archinte.167.1.31

153. Feigelson HS, Caan B, Weinmann S, Leonard AC, Powers JD, Yenumula $\mathrm{PR}$, et al. Bariatric surgery is associated with reduced risk of breast cancer in both premenopausal and postmenopausal women. Ann Surg. (2019). doi: 10.1097/SLA.0000000000003331. [Epub ahead of print].

154. van Gemert WA, Schuit AJ, van der Palen J, May AM, Iestra JA, Wittink H, et al. Effect of weight loss, with or without exercise, on body composition and sex hormones in postmenopausal women: the SHAPE-2 trial. Breast Cancer Res. (2015) 17:120. doi: 10.1186/s13058-015-0633-9

155. Chlebowski RT, Blackburn GL, Thomson CA, Nixon DW, Shapiro A, Hoy MK, et al. Dietary fat reduction and breast cancer outcome: interim efficacy results from the Women's Intervention Nutrition Study. J Natl Cancer Inst. (2006) 98:1767-76. doi: 10.1093/jnci/djj494

156. Saxe GA, Rock CL, Wicha MS, Schottenfeld D. Diet and risk for breast cancer recurrence and survival. Breast Cancer Res Treat. (1999) 53:241-53. doi: 10.1023/A:1006190820231

157. Bauer J, Biolo G, Cederholm T, Cesari M, Cruz-Jentoft AJ, Morley JE, et al. Evidence-based recommendations for optimal dietary protein intake in older people: a position paper from the PROT-AGE Study Group. J Am Med Dir Assoc. (2013) 14:542-59. doi: 10.1016/j.jamda.2013.05.021

158. Buommino E, Boccellino M, De Filippis A, Petrazzuolo M, Cozza V, Nicoletti $\mathrm{R}$, et al. 3-O-methylfunicone produced by penicillium pinophilum affects cell motility of breast cancer cells, downregulating alphavbeta5 integrin and inhibiting metalloproteinase-9 secretion. Mol Carcinog. (2007) 46:930-40. doi: $10.1002 / \mathrm{mc} .20322$

159. Fiorelli A, Rizzo A, Messina G, Izzo A, Vicidomini G, Pannone G, et al. Correlation between matrix metalloproteinase 9 and $18 \mathrm{~F}-2$-fluoro-2deoxyglucose-positron emission tomography as diagnostic markers of lung cancer. Eur J Cardiothorac Surg. (2012) 41:852-60. doi: 10.1093/ejcts/ezr117

160. Fiorelli A, Morgillo F, Fasano M, Vicidomini G, Di Crescenzo VG, Di Domenico $\mathrm{M}$, et al. The value of matrix metalloproteinase -9 and vascular endothelial growth factor receptor 1 pathway in diagnosing indeterminate pleural effusion. Interact. Cardiovasc. Thorac. Surg. (2013) 16:263-9. doi: 10.1093/icvts/ivs466

161. Grimaldi A, Santini D, Zappavigna S, Lombardi A, Misso G, Boccellino M, et al. Antagonistic effects of chloroquine on autophagy occurrence potentiate the anticancer effects of everolimus on renal cancer cells. Cancer Biol Ther. (2015) 16:567-79. doi: 10.1080/15384047.2015.1018494

162. Pastina P, Nardone V, Croci S, Battaglia G, Vanni F, Bellan C, et al. Anti-cancer activity of dose-fractioned $\mathrm{mPE}+/$ - bevacizumab regimen is paralleled by immune-modulation in advanced squamous NSLC patients. $J$ Thorac Dis. (2017) 9:3123-31. doi: 10.21037/jtd.2017.08.68

163. Ricciardiello F, Caraglia M, Iorio B, Abate T, Boccellino M, Colella G, et al. Aggressiveness pattern and second primary tumor risk associated with basaloid squamous cell carcinoma of the larynx. Oncotarget. (2017) 8:95791-8. doi: 10.18632/oncotarget.21327
164. Reggiani F, Labanca V, Mancuso P, Rabascio C, Talarico G, Orecchioni $\mathrm{S}$, et al. Adipose progenitor cell secretion of gm-csf and mmp9 promotes a stromal and immunological microenvironment that supports breast cancer progression. Cancer Res. (2017) 77:5169-82. doi: 10.1158/0008-5472.CAN-17-0914

165. Christiaens V, Lijnen HR. Role of the fibrinolytic and matrix metalloproteinase systems in development of adipose tissue. Arch Physiol Biochem. (2006) 112:254-9. doi: 10.1080/13813450601093567

166. Motrescu ER, Rio MC. Cancer cells, adipocytes and matrix metalloproteinase 11: a vicious tumor progression cycle. Biol Chem. (2008) 389:1037-41. doi: 10.1515/BC.2008.110

167. Saijo H, Hayashida K, Morooka S, Fujioka M. Combined treatment with artificial dermis and basic fibroblast growth factor for cranial bone-exposing wounds. J Tissue Viability. (2015) 24:173-9. doi: 10.1016/j.jtv.2015.08.002

168. Eo S, Kim Y, Cho S. Vacuum-assisted closure improves the incorporation of artificial dermis in soft tissue defects: Terudermis( $(\mathbb{R})$ and Pelnac( $(\mathbb{R})$. Int Wound J. (2011) 8:261-7. doi: 10.1111/j.1742-481X.2011.00780.x

169. Suzuki S, Morimoto N, Yamawaki S, Fujitaka J, Kawai K. A case of giant naevus followed up for 22 years after treatment with artificial dermis. J Plast Reconstr Aesthet Surg. (2013) 66:e229-33. doi: 10.1016/j.bjps.2013.03.018

170. Recht A, Solin LJ. Breast-conserving surgery and radiotherapy in early-stage breast cancer: the importance of local control. Semin Radiat Oncol. (2011) 21:3-9. doi: 10.1016/j.semradonc.2010.08.001

171. Mendenhall S, Anderson L, Ying J, Boucher K, Liu T, Neumayer L, et al. The BREAS trial: stage I. outcomes from the time of tissue expander and acellular dermal matrix placement to definitive reconstruction. Plastic Reconstr Surg. (2015) 135:29e-42e. doi: 10.1097/PRS.0000000000000758

172. Fruh SM. Obesity: risk factors, complications, and strategies for sustainable long-term weight management. J Am Assoc Nurse Pract. (2017) 29(S1):S3-14. doi: $10.1002 / 2327-6924.12510$

173. Chastain CA, Klopfenstein N, Serezani CH, Aronoff DM. A clinical review of diabetic foot infections. Clin Podiatr Med Surg. (2019) 36:381-95. doi: 10.1016/j.cpm.2019.02.004

174. Kato Y, Iwata T, Morikawa S, Yamato M, Okano T, Uchigata Y. Allogeneic transplantation of an adipose-derived stem cell sheet combined with artificial skin accelerates wound healing in a rat wound model of type 2 diabetes and obesity. Diabetes. (2015) 64:2723-34. doi: 10.2337/db14-1133

Conflict of Interest Statement: The authors declare that the research was conducted in the absence of any commercial or financial relationships that could be construed as a potential conflict of interest.

Copyright $\odot 2019$ Di Domenico, Pinto, Quagliuolo, Contaldo, Settembre, Romano, Coppola, Ferati, Bexheti-Ferati, Sciarra, Nicoletti, Ferraro and Boccellino. This is an open-access article distributed under the terms of the Creative Commons Attribution License (CC BY). The use, distribution or reproduction in other forums is permitted, provided the original author(s) and the copyright owner(s) are credited and that the original publication in this journal is cited, in accordance with accepted academic practice. No use, distribution or reproduction is permitted which does not comply with these terms. 